\title{
Future Guanabara Bay Clean-up: Rio de Janeiro's Hillslope Favelas Ought to Be its Amicable Pinnacles
}

\author{
Nilo S. C. Serpa ${ }^{1,2}$; Charles W. Finkl ${ }^{3}$; Richard B. Cathcart ${ }^{4}$ \\ ${ }^{I}$ Centro Universitário ICESP, Águas Claras, Brasília, Brasil DF; ${ }^{2}$ Université des Sciences de L'Homme, Paris, France. \\ ${ }^{3}$ Florida Atlantic University, Boca Raton, Florida 33431, USA. \\ ${ }^{4}$ GEOGRAPHOS, Burbank, California USA.
}

Corresponding author: nilo.serpa@icesp.edu.br

Received:_20 Oct 2020_/ Accepted:_04 Dec 2020_/ Published:_31 Oct 2021_.

\section{To Alexander Bolonkin, in memoriam...}

\begin{abstract}
This article brings a social discussion about the surroundings of Guanabara Bay, showing that there are technological instruments capable of promoting citizenship and quality of life for the inhabitants of the slum areas. The work is part of the collection of published studies on the Guanabara Bay edited by the electronic journal CALIBRE, integrating a fundamental legacy for future projects in urban ecology.
\end{abstract}

Key words: favelas, escalators, Guanabara Bay, Macro-Imagineering, asfaltos, favelados.

Resumo: O presente artigo traz uma discussão social acerca do entorno da Baía de Guanabara, mostrando que há instrumentos tecnológicos capazes de promover cidadania e qualidade de vida para os habitantes das áreas favelizadas. O trabalho se insere na coleção de estudos sobre a Baía de Guanabara publicados no periódico eletrônico CALIBRE, integrando legado fundamental para futuros projetos em ecologia urbana.

Palavras-chave: favelas, escalators, Baía de Guanabara, Macro-Imagineering, asfaltos, favelados. 


\section{Introduction}

Prior to AD 1957 Homo sapiens' Space Age commencement, the "overview effect" generally referred to the human experience of viewing landscapes from above, such as from atop high hills and even mountain summits [1]. A new way of looking at geographical reality assists our individual freedom to choose, reaffirms and amplifies our everyday understanding, and usually motivates people to convert technological innovations into marked visible regional changes driven by public rationality and consent. Obstructionism is the nemesis of constructionism. On 15 February 1875, the blessed populace of Rio de Janeiro gazed at an awesome sky-backgrounded example of an outer space sporadic aurora and, from 28 April 2021 Brazil has begun its national attempt to establish an orbital rocket launch capability at its Centro de Lançamento de Alcântara situated on Brazil's northern coast, about 2 degrees south of Earth's Equator. By early-2021 AD, the city of Rio de Janeiro had extended its cooperative disaster preparedness partnership with the NASA twofold: to increase situational awareness and governmental response to environment-related disasters and to foster the propagation of science education throughout local schools and to create an informed public [2]. In childhood, human imagination helped each of us to see fascinating shapes in scudding clouds but, much more than whimsy, many human imaginations used with intention can give shape to dreams and future goals. Perhaps one of the most important experiences people ponder and sometimes heed during life will be to reduce human fixation on highly rationalized, even doublespeak [3], so-called sustainability [4] and, instead focus more on susceptibility, our God-given openness to the beneficial and lifeenhancing "overview effect”!

As optimistic coastal planners [5] seeking and fervently desiring to stimulate (after September 2021) all of Rio de Janeiro's existing, inherently green favelas built by long-term focused autotelic activities to become more accessible, safer, healthier, infrastructurally efficient, beautiful and resilient, constantly driving these self-built and illegally-established occupations of public and private landscapes usually mapped as unofficial non-jurisdictions - toward permanent prosperity. But, in particular, and chiefly because most of the city waste dangerously deposited in Guanabara Bay (GB) is derived from these densely urbanized but distinctly separated hillslope regions [6], it is hoped to transform (for the better) eight essential municipalities (Rio de Janeiro, São João de Meriti, Duque de Caxias, Magé, Guapimirim, Itaboraí, São Gonçalo and Niterói), a total land area of 2,766 km² bordering the $384 \mathrm{~km}^{2}$ GB! "Pinnacle" means the highest elevation of a topographic place and also a notable capping architectural ornament. Our task of beautifying landscape architecture-focused coastal planners is to generate a feasible Macro-Imagineering project vision for favela dwellers - people who have demonstrated for

decades competency in determinedly changing their given geophysical and social world as well as the resulting pride achieved through personalized self-efficacy — that is of durable dimensions and obvious affordability.

Accomplished youth native to downtown Rio de Janeiro ordinarily is more likely to achieve positive public recognition than their disadvantaged peers living in the closely adjacent favelas - this outcome may be referred to 
as the intra-urban "escalator effect" [7]. Improved mobility, sanitation, reliably clean potable freshwater and noninterruptible electricity supply serving favela dwellers could reduce the "escalator effect" impact markedly. The unitized technology of latticed and covered outdoor escalators is symbolic; meant to last for generations after construction, numerous installed mobility devices obviously transcend its everyday freight-delivery and passenger travel function [8]. Cheerfully neon-lit during nighttime, such trip efficient steep incline machines, potentially laid out in a sea-level viewer attractive trellis-like pattern, might overcome some social barriers long-imposed by misinformed or ignorant politicians and sometime unsociable extra-favela elites, the most influential citizens of Rio de Janeiro [asfaltos] — persons almost limited to exotelic actions only, motivated by an extraneous goalwho evince disregard for self-starters, the decent favela residents of high-density, low-cost homes built by hand! Brazil-recorded videos and movie comedies generally feature characters from favelas, persons attempting to better themselves, often by currently illegal means; for example, Jorge Alberto Furtado's O Homem que Copiava (2003) is a funny expose of the unfortunately too-common "cultural trait" of wealth acquisition based on just social status, unleavened unjust greed and, perhaps, truly malicious public deceit done by clever publicity release specialists-for-hire.

\section{A brief social history of the favelas in Rio de Janeiro: impacts on Guanabara Bay}

The first irregular occupations in the city of Rio de Janeiro occurred from the large number of victorious soldiers from the "Canudos War", who landed in Rio at the end of 1897 without housing, and the great concentration of Africans and Afro-descendants who filled the city after the abolition of slavery. However, occupations in shacks are still earlier, dating back to the 1850 s, as is the case with the historical "Morro da Mangueira".

The social structure of the classic favelas of Rio de Janeiro is quite complex. By classic favelas we mean povertystricken communities that have grown since the second half of the 19th century, developing a popular culture largely influenced by the rituals and customs of "Candomblé" and "Umbanda" and, later, materialized in festive manifestations around the themes of "Samba", such as the famous carnival parades and the circles of "Partido Alto". Marked by social exclusion and absence of public power, these communities evolved in disarray, climbing the slopes of the city's several hills, developing their own moral rules shaped by the harsh exercise of survival. Evidently, the abandonment scenario gave rise to criminality, at first characterized by the profile of the "malandro", basically the common thief who is a street robber.

Although social science theorists insist on a simplistic model for analyzing crime — which ignores innate individual tendencies - , the fact is that the number of criminals in the favelas of Rio de Janeiro has always constituted a very small part of the population. We must add to this the error of assuming that favelas residents want to get out of it. On the contrary, a more accurate anthropological analysis shows that the crystallized social system of the favelas not only reflects the cultural identity of their residents, but is not replicable in projected 
urban areas (the example of the "Cidade de Deus" confirms this fact!). What residents want is citizenship, that is, social inclusion (in other words, education, security, health and sanitation).

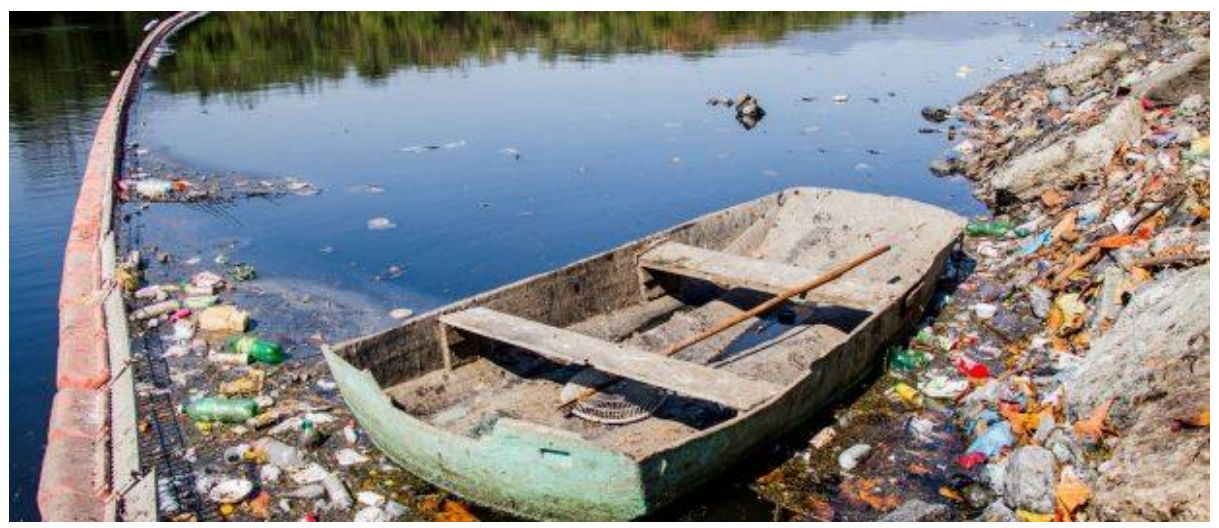

Figure 1 - Surroundings of Canal do Cunha (photo by Elizângela Leite, 2017).

With disorderly growth and continuous distance between public power and favelas, crime took the form of drugtrafficking gangs - enticing minors through a regime of terror and exploitation of poverty — and endemic militias, both nourished by the government corruption of a pseudo-democracy that boils down to the exercise of mandatory voting. Over time, favelas descended the hills, extending along the shores of GB, through the "Complexo da Maré" and "Complexo do Alemão", greatly increasing the load of untreated organic waste and garbage on the edges of the Bay. The "Complexo da Maré", once the largest favela on over-bay stilts in Rio de Janeiro, is now partially urbanized. However, the risk of disease in the region appears to be, more or less, rather permanent, especially adjacent to the exposed tributaries of the highly polluted "Canal do Cunha" (Figure 1), near the "Ilha do Fundão", whose foreboding dark-hued waters flow into GB's turbid waters. The accumulation of contaminated materials, solid waste and large volume of domestic and industrial sewage contribute to dramatically increase pollution rates.

Certainly, conventional proposals will not solve the problem of pollution in GB, as we have pointed out in a collection of works on the subject [10]. Common ecological barriers are palliative for a macro-problem whose solution requires infrastructure, social inclusion and innovative thinking in urban ecology. Realizing that extraction of micro-plastics from GB seafloor is currently economically impossible, nevertheless we hope some type of natural means will be fostered - perhaps a kind of kelp which can be harvested? We recently started work on the possibility of setting up small floating plant islands, constituting an auxiliary network for organic renewal of the most polluted areas of GB. This work is in progress and will give rise to new publications.

\section{Zen-like approach to a municipality-driven Guanabara Bay restoration}

Emphasizing intuition and profession insights, instead of a conventional fixation on timetabled specific goals, the focus of the proposals contained in this brief article is to develop an enduring and prosperity-inducing 
reconciliation between $\sim 1.5$ million favelados, $\sim 25 \%$ of the region's residents, unserved by, or comprehensively over-charged for, basic civic servicing infrastructure such as sewerage, freshwater supply and electricity, and their encompassing bayfront-located Rio de Janeiro society living in utility-connected downtown skyscrapers. Bluntly, every person living and working in the area disposing of waste in a careless manner is a desecrator. Since at least $1930 \mathrm{AD}$, and until circa AD 1980, some heartless or authority-compliant Brazilian urban planners sought the physical eradication of all favelas. Later, managerial schemes entailed limited and regularized utility upgrades, as well as stronger economic integration with downtown residences, port facilities, factories and offices. The elite political class representing the formal city - those asfalto folks who sought and strived to "obliterate" Rio de Janeiro's informal slums by inducing their Internet “invisibility” (i.e., Google Earth), hidden from potential and camouflaged from view of actual foreign tourists and other hoaxed visitors from afar, especially during internationally celebrated costly symbolic cultural events whilst, at the same time, using the term favela as an associated label for an advertised sellable retailed entertainment product! After AD 1988 geographical low-landers voiced some interest in latching the favelas more securely to the core district, the downtown, but the key geographical transformation needed by so many persons was never legally accomplished, or financed: the simple organizational recognition by established governmental bodies that effectively administered favelas are regions with mapped political borders, entitled to govern themselves through resident-approved advisory groups and specialized councils and constantly trying (as enfranchised Brazilians) at all times to harmonize their community actions with those extant throughout the State and Nation socio-ecosystems [9a-9b].

Nevertheless, only $\sim 30 \%$ of the populace of the whole GB-fronting urban region - measuring $52.27 \%$ of the State's area - remain unconnected to a unified, government-operated sanitation system, and only $50 \%$ of all State-generated sewage (replete with atrocious volumes of floating litter) is treated before it flows through multiple air-exposed waterways into a disgracefully degraded Guanabara Bay [10]. (Often it is specified that safe sewage systems epitomize human civilization — Chelsea Wald's 2021 tome Pipe Dreams: The Urgent Global Quest to Transform the Toilet.) Rio de Janeiro has more favelados that any other urbanized place in Brazil; Rio de Janeiro's first historically recorded favela was Morro da Providência (begun circa AD 1897) and its areally most extensive - about $144 \mathrm{~km}^{2}$ — is Rocinha (begun circa 1940 AD). Rocinha's people can watch a dedicated television station (TV ROC) and, probably, $\sim 80 \%$ of favelados therein have Internet connection! Naturally, a pertinent question arose: exactly when was it that downtown's High-Society first noticed that steep hillside residents enjoy a less expensive life-style and can admire superior vistas of their commonly-shared, but sadly defiled, GB than those working and housed in expensive tall buildings built downtown; perhaps some the basic daily animus toward favelados expressed or, oftentimes, hidden by whispering or shouting asfaltos simple derives from this singular causal geographical fact of a rocky naturally punctuated landscape. For a moment contemplate the total removal of Rocinha, its veritable erasure from the picturesque landscape by asfalto-mandated bulldozers and other industrial-scale object-moving machinery. If the favelados exited peacefully they would take much more 
than their personal grooming, clothing items and furniture - since they provably built their individually consecrated "dream" homes (including architectural elements such as concrete bricks, wiring, plumbing etc.) then all such materials comprising those homes in toto can become mobilized assets taken, shifted elsewhere! Next, macro-imagine the possible post-2010 AD unnatural disasters occurring subsequently — landslides, flash floods, mudslides and much, much more [11-12]. Indeed, mitigation of geological hazards requires experts to properly anticipate, to identify at-risk steep landscape regions, and to effectively inform favelados and to recommend design alterations to their present-day infrastructure. Absent such work, in essence, favela removals could worsen the existing GB's uglifying and too-evident pollution! Oddly, non-totalistic event-anticipating eager asfaltos are busying themselves strategizing a publicly-acceptable landscape plan to successfully accommodate downtown's fixed-in-place capital assets to a postulated future local sea-level rise, including marine-estates, floating aquatic GB seafood production systems, adapted merchant and naval port industries [13], floating shipyards maritime transport developments, post-COVID 19 cruise liners and park-like coastal ecological zones [14].

\section{4. "Disneyfied" Rio de Janeiro favelas? Power from the People!}

Uneven geographical development in Rio de Janeiro intrigues Brazilian and overseas landscape planners, drawing some to Macro-Imagineering. As a former Floridian, Dr. Charles W. Finkl knows personally the astounding regional developmental effects of the Reedy Creek Improvement District's establishment during mid-1967 AD, wherein eventually Walt Disney World was constructed by traditional means and methods [15]. However, the worldwide milieu of outdoor construction has changed markedly, especially during the early $21^{\text {st }}$ Century. The idea of additive three-dimensional material printing technology dates, approximately, from AD 1983 and the first working printer was assembled by 1984 AD. 3-D printing of buildings, building components and building furnishings are the future of construction, in both robotized mass-market and serendipitous incarnations. "By producing bridges and houses more cheaply and efficiently, 3D printing could reduce concrete's carbon footprint — but it could also just encourage engineers to build more" [16]. Cleanliness symbolizes all Disney theme parks.

Soils - that is, "earth" - is the most ancient as well as one of the most modern ingredients for $21^{\text {st }}$ Century constructions; too, since "cement" has been useful since olden times it must be included in that category of global things found important to the individual daily lives of millions of human beings [17]. Such manipulable materials are ubiquitous; 3D printing's recent perfection has prompted and hastened major innovations in many other closely associated fields of endeavor, including Art! (GOTO: http://myminifactory.com for a huge selection of open-source digital scans of famous artworks, furniture, house decorations that can be printed by nonprofessionals.) Even today, as in the past, and known in the Portuguese language as "taipa", rudimentary rammedearth walls are still prominent in Brazil [18]. Regularization and normalization of the technology of large-scale 3D infrastructure printing is Green, entailing no left-over or waste materials, and ought to be insurable since the plans 
may be provided by certified architects and macro-engineers! Printed homes have been completed in Mexico (2019) and the USA (2021).

Hundreds of new and replacement homes for favelados may, thusly, be fabricated off-the-cuff so to speak. Necessarily, electrical power for the towed trailer-mounted portable printing machines will have to be available 24/7/365. Down-to-earth Brazilian "Slartibartfasts" intending to successfully build bespoke new residences, or upgrade old residences, will take on the aura of Neo-Impressionist pointillistic artists that would make Douglas Adam (1952-2001) proud - each to his own taste. Neighborhoods within each favela might collectively decide that a particular style and coloration of home exterior is preferred by the consenting cooperative group! Reliable distributed micro-generated electricity for local consumption may be produced by solar panels or cheaper small wind-turbines [19]. For example, child-safe because the lack of any external moving parts, approximately the size of a standard street fire-hydrant, a $1 \mathrm{~kW}$ PowerPod — designed and put together by Halcium (headquartered in Salt Lake City, Utah, USA: https://www.halcium.com ) - are inconspicuously-sized turbines that capture wind from every direction, speed it up to achieve an output worthy of admiration, and can be colorfully paint-coated to reflect local tastes! (Figure 2).

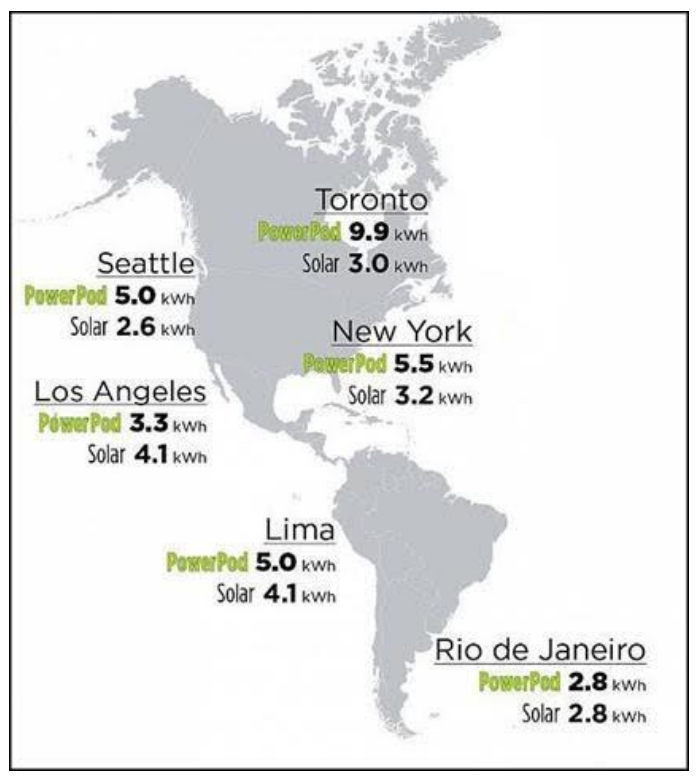

Figure 2. A single PowerPod versus ordinary linked silicon-wafer solar panel, 24-hour average electricity production at Rio de Janeiro. Favelados can easily live off-the-grid. That means the makeshift transmission lines now serving such communities, and which pose a life-threat to inhabitance, may be removed permanently. Besides, almost $50 \%$ of Rio de Janeiro State's electricity in imported from other States at some considerable expense. This mini-windmill need only be secured to a stable structural surface (roof, wall, platform etc.) and were carefully designed for already developed urban locales such as favelas. (Google Images). 


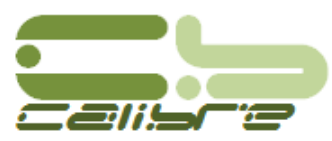

\section{Escalating the on-going effort to cleanse Guanabara Bay, Rio de Janeiro, Brazil}

Rio de Janeiro's most ancient favela, Morro da Providência [20], is a fine viewpoint for people wishing to distance-observe the superficially beautiful Guanabara Bay. Walt Disney World is located in Central Florida, USA. It features a unique waste disposal system of "utildors" — officially named the "Automatic Vacuum Collection (AVAC)" — which "...pulls trash underground in pneumatic tubes and moves it at...[ 98 $\mathrm{kph}$ ]...directly from the trash cans to a central compacting plant" [21]. Why not use above-ground sited electrified favela escalator chute-shaped sub-structures as "utilidors" as well as subterranean conduits for compartmentalized fiber-optic cabling, powerlines, sewage piping and freshwater importation? This extension of “utilidor' uses seems to fit well with the publicly-known climate change mitigation policies currently be formulated for Rio de Janeiro [22]. Outdoor escalators are less costly to construct than funiculars, cog-railways and rack-and-pinon railways (Trem do Corcovado) In fact escalators were installed during AD 2003 to move passengers to and from the famed Cristo Redentor. Since the first patent was awarded in AD 1892, escalators have been a useful mobility technology for decades, according to editor Alisa Goetz's Up, Down, Across: Elevators, Escalators, and Moving Sidewalks (2003). Generally, such devices are safe, but escalator-related injuries can result in emergency department treatment [23].

In Columbia, the Mayor of Medellin during 2008-2011, Alonso Salazar Jaramillo, oversaw the installation and first use of a long solar-powered outdoor escalator — in the Spanish language, the escaleras electricas — which connects peripheral poor neighborhoods to that city's valley central business district (Figure 3), reducing the travel time from one-half hour to a mere six minutes [24-25].

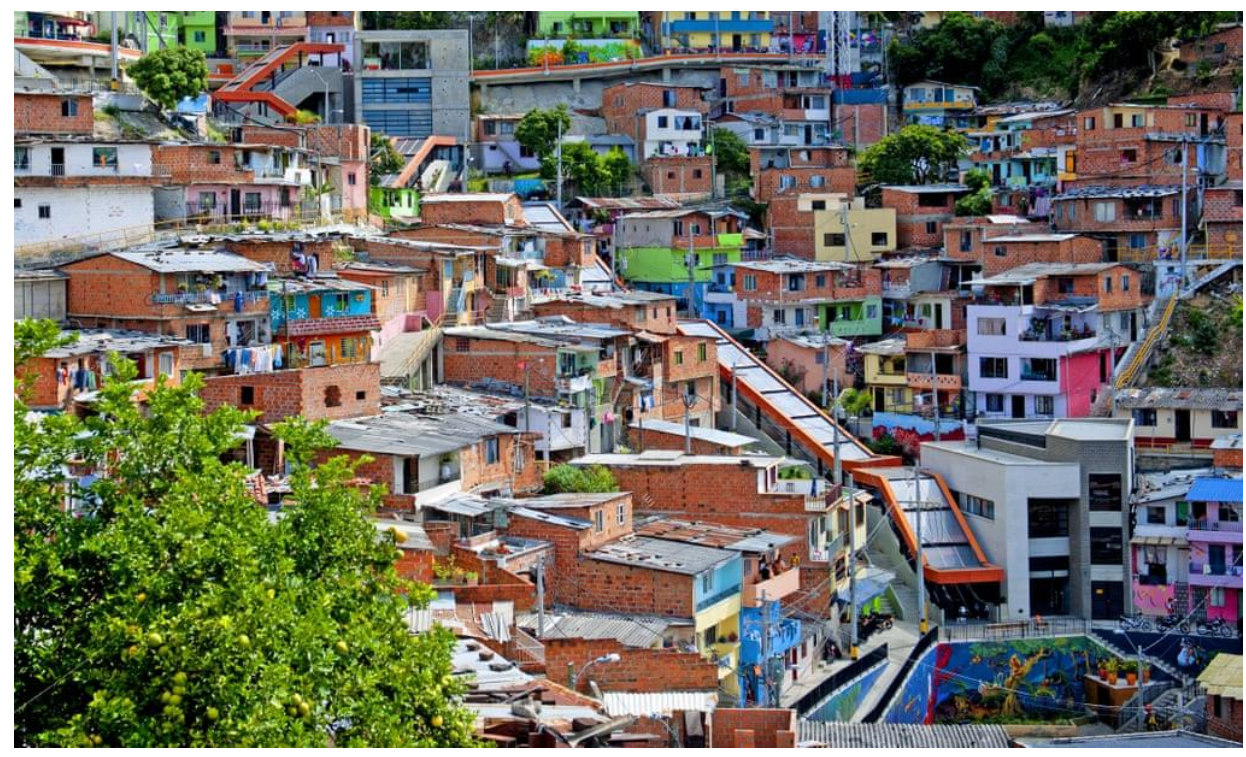

Figure 2. The escaleras electricas.(Google Images). 


\section{Conclusion}

Citizenship seems to have become an inaccessible right for those who constitute the huge portion of excluded people across the planet. This exclusion tends to grow as the billionaire fortunes of men who intend to increase their wealthy by fabricating frivolities such as space cruises and desert blizzards, while humanity suffers from the worst ailments of the globalization. It is difficult to understand that so much greed of the few surpasses the most basic needs of the many, with several simple and economically viable solutions to most social and environmental problems. What a dark power is this that decides who survives and who succumbs!

Favelas are today the hideouts of a crime that finances power in many regions, and therefore, in general, they cannot be targets of citizenship policies. Its inhabitants live at the mercy of a parallel power imposed by fear and intimidation. As we have seen in this article, there is no lack of ideas and technology to support the actions of public authorities in favor of quality of life and dignity for all. It remains to be seen whether at some time there will be those who are willing to invest in the true civilization that we may not even deserve.

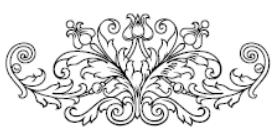

\section{References}

[1] White, Frank (1987) The overview effect: Space exploration and human evolution. Boston MA: Houghton Mifflin. Page 1.

[2] Hurtwitz, M.M. et al. (September 2020) "Earth Observations Inform Cities' Operations and Planning" Eos 101: 29-33.

[3] Walker, A.C. et al. (2021) "Controlling the narrative: Euphemistic language affects judgments of actions while avoiding perceptions of dishonesty” Cognition 211: 104633.

[4] Ford, A.T. et al. (2021) "Understanding and avoiding misplaced efforts in conservation" FACETS 6: 252-271.

[5] Edwards, N. (1 March 2021) "Politics of the coastal professional" Ocean \& Coastal Management 202: 105419.

[6] Serpa, N. and Cathcart, R.B. (February 2020) "Guanabara Bay Special Edition: Including unpublished PARTS III and IV" Revista Brasiliense de Engenharia e Fisica Aplicada 5: 1-36. 
[7] Davies, J. Donnelly, M. and Sandoval-Hernandez, A. (13 March 2021) "Geographies of elite higher education participation: An urban 'escalator' effect” British Educational Research Journal https://doi.org/10.1002/berj.3711 . 23 pages.

[8] SEE: Townsend, D. (5 January 2021) "Can escalators and elevators solve the last-mile problem?" City Monitor. https://citymonitor.ai/transport/can-escalators-and-elevators-solve-the-lastmile-problem .

[9a] Barbosa, L.M. and Walker, G. (2020) "Epistemic injustice, risk mapping and climatic events: analyzing epistemic resistance in the context of favela removal in Rio de Janeiro" Geographic Helvetica 75: 381-391.

[9b] Rulim, C.C. and Baptista, P. (2021) "Sharing Lisboa [Portugal]: A Digital Social Market to Promote Sustainable and Energy Efficient Behaviors" Climate 9: 1-28.

[10] Serpa, N. and Cathcart, R.B. (February 2021) "The Devil on a Dying Bay: Brazilian Marine Plasticarianism at Guanabara Bay" Revista Brasilience de Engenharia Fisica Aplicada 6: 1-24

[11] Tarolli, P., Preti, F. and Romano, N. (2014) "Terraced landscapes: From an old best practice to a potential hazard for soil degradation due to land abandonment" Anthropocene 6: 10-25.

[12] Ehrlich, M. et al. (2021) "Triggering factors and critical thresholds for landslides in Rio de Janeiro-RJ, Brazil” Natural Hazards 107: 937-952.

[13] Hossain, T. et al. (2021) "Role of sustainability in global seaports" Ocean and Coastal Management 202: 105435.

[14] Baumeister, J., Bertone E. and Burton, P. (Eds.) (2020) SeaCities: Urban Tactics for Sea-Level Rise. The Netherlands: Springer. 321 pages.

[15] Bezdecny, K. (2015) "Imagineering Uneven Geographical Development in Central Florida" Geographical Review 105: 325-343.

[16] Zastrow, M. (6 February 2020) “The new 3D printing” Nature 578: 20-23.

[17] Goodbun, J.C. (2016) "Mud and Modernity" ARENA: Journal of Architectural Research 1:115.

[18] Rauch, M., Heringer, A. and Blair-Howe, L. (2019) Upscaling Earth: Material, Process, Catalyst. Gta Verlag: FRG. 170 pages.

[19] Milojevic, M. et al. (2021) "Household's Energy Autonomy: Risks or Benefits for a State?" Energies 14: 2026.

[20] Worms, J. and Shuyter, A. (2018) "Conceived versus Lived Social Spaces and the Transformation of the Morro da Providencia Favela of Rio de Janeiro Since 2008" The Latin Americanist 62: 545-567. 


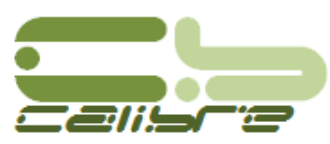

[21] Mittermeier, S. (2021) A Cultural History of the Disneyland Theme Parks: Middle Class Kingdoms. Chicago, Ill.: Intellect. Page 67.

[22] da Silva, T.B., Baptista, P., Silva, C.A.S and Santos, L. (2020) "Climate Change Mitigation in the Transportation Sector in Rio de Janeiro, Brazil” Environments 7: 99.

[23] Schminke, L.H. et al. (March 2013) "Riding the Escalator: How Dangerous is it Really?" Western Journal of Emergency Medicine XIV: 141.

[24] Naef, P. (October 2016) "Touring the 'comuna': memory and transformation in Medellin, Columbia" Journal of Tourism and Cultural Change. Pages 1-17.

[25] Reimerink, L. (2018) "Planners and the Pride Factor: The Case of the Electric Escalator in Medellin” Bulletin of Latin American Research 37: 191-205. 